\title{
An Analysis of Fungal Infection in Some Economically Important Freshwater Fishes of Mayanur Dam, Karur District, Tamil Nadu, India
}

\author{
K. Bharath Kumari and R. Sivakami* \\ Department of Zoology, Arignar Anna Government Arts College, Musiri-621211, \\ Tamil Nadu, India \\ *Corresponding author
}

\begin{abstract}
A B S T R A C T
Keywords

Achlyaspecies,

Fungal infections,

Fresh water, Fish

culture

Article Info

Accepted:

10 December 2017

Available Online:

10 January 2018

With increasing human population, freshwater fish culture has been intensified throughout the world as fish is a source of cheap animal protein. However, aquatic fungi have an important bearing on fish health. Hence the present study was aimed at analyzing the commonly occurring fungi in a fresh water system in Tamil Nadu and assessing their infection on fishes. Results reveal that among the three seasons, maximum fungi (16 species) were recorded in the rainy season; while the fish that had the least amount of infection was Anabas and the fish that recorded maximum infection was Catla. Among the various fungal species, Achlyaamericana recorded maximum infection rates in all the three seasons.
\end{abstract}

\section{Introduction}

With exploding human population, India will have to utilize all its avenues for providing a nutrient rich food to its masses. With fish being a good source of nutrient rich protein, fresh water culture has been intensified throughout the world. Even though fish production has increased manifold, today, aquaculturists are being met with diseases limiting their production and profitability. Among the various disease causing agents, fungal agents have been known to cause a number of diseases. Within the aquatic fungi, species of Oomycetes have special importance because of their impact on fish health (West,
2006). In addition, many workers (Sati, 1991; Chauhan and Qureshi, 1994; Qureshiet al., 2002) have also reported that fungi belonging to Saprolegnia, Pythium, Aphanomyces, Dictyuchus and Achlya are some of the most virulent parasites. Hence the present study was aimed at identifying the commonly occurring aquatic fungi in a fresh water system as well as its impact of fish infection grown in this system.

\section{Materials and Methods}

Five economically important freshwater fishes viz., Catla catla, Notopterus chitala, Channa striatus, Labeo rohita and Channa marulius 
were collected in Mayanur region, Cauvery River, Karur District, Tamil Nadu during January to December 2016. The fishes were collected with the help of fisherman in sterile polythene bags in aerated water and transported immediately to the laboratory, for mycological study. The fishes were kept in separate in glass aquaria with continuous air supply at ambient temperature. Isolation of fungi from infected fishes were carried out by taking small pieces from muscles (about $2 \mathrm{~mm}$ in diameter) from different portions of body and washed thoroughly with distilled water. These tissues were then inoculated over plates containing different culture media viz., Potato Dextrose Agar medium (Peeled potato-250gm, Dextrose-20gm, Agar-15gm, Distilled 1000ml), Richard's medium (Potassium nitrate 10gm, Potassium dihydrogen phosphate $5 \mathrm{gm}$, Magnesium sulphate $2.50 \mathrm{gm}$, Ferric chloride 0.02gm, Sucrose 50gm, Distilled water 1000ml) and Czapek-Dox Agar medium (Agar 15.0gm Sodium nitrate 2.0gm, Potassium dihydrogen phosphate $1.0 \mathrm{gm}$, Magnesium sulphate $0.5 \mathrm{gm}$, Ferrus sulphate $0.01 \mathrm{gm}$, Sucrose $30.0 \mathrm{gm}$, distilled water $1000 \mathrm{ml})$. Streptomycin $(50 \mathrm{mg} / \mathrm{l})$ was added in the medium to avoid bacterial contamination. Among the three media, the Potato Dextrose Agar medium was found to be the best medium for invariably all the isolated fungi. An average three to seven days of incubation at a temperature ranging between 26 and $32^{\circ} \mathrm{C}$ in the incubator was provided to the different isolated fungi.

Identification and characterization were made by observing the colony colour and texture and the prepared slides by comparing with authentic manuals (Raper and Thom, 1949; Barnett and Hunter, 1972; Cooney and Emerson 1964; Samson and Tansey 1977; Domsch et al., 1980, Bilgrami et al.,; 1991, Jamaluddin, 2004). Unidentified species, devoid of fruiting bodies were designated as sterile mycelia. The seasonal variation and percentage of infection of fishes were analyzed. The percentage of frequency of fungal species occurrence was calculated as follows:

Percentage of Frequency of Species =

$\frac{\text { Average number of total colonies of species in one plate }}{\text { Average number of total colonies of all the species in one plate }} \times 100$

\section{Results and Discussion}

The fungi that were isolated in the aquatic system is presented in Table 1. As evident from the table, a total of 16 species belonging to 10 genera could be identified. Of these, four species belonged to the genera Achlya, two species each to Aspergillus, Pythium and Saprolegnia and one each to the genus Allomyces, Aphanomyces, Hiraustotheca, Chaetomium, Dychuchus and Alkharia.

Amongthe four species of Achlya, A. Americana dominated even though all the Achlya species were perennial. Within the two Pythium species, $P$. aphanidesmatum occurred only during the rainy season while among the two species of Saprolegnia both were absent during the summer season. Within the Aspergillus species, A. fumigatus dominated over A. niger even though both were perennial. The other perennial species were Allomyces anomatus and Aphanomyces laevis and both dominated during the rainy season. Species like Hiraust itheca, Chaetomium, Dychuchus and Alknaria were recorded only during the rainy season.

On the whole, 11 species were recorded during the pre-summer season, eight species in the summer season and all the 16 species in the rainy season. Thus, it is clearly evident that all the fungal species in the present study preferred the rainy season. A perusal of 
literature reveals that Rashmi Kumari and Chandan Kumar (2015) while studying fungal infection in fishes in a fresh water system in Bihar also reported maximum occurrence of fungi in October and minimum in June. This correlates with the present study as maximum fungal diversity was recorded in rainy season
(August-November) and minimum in summer (April-July). The maximum diversity present during the rainy season could be attributed to optimum temperature as well as enhanced nutrient levels present during this time due to increased run-off entering the system.

Table.1 Pathogenic fungi isolated from the fresh water aquatic system of Mayanur Dam

\begin{tabular}{|c|c|c|c|c|}
\hline S. No. & Species of Fishes & $\begin{array}{l}\text { Pre-summer } \\
\text { season } \\
\text { (Dec-Mar) }\end{array}$ & $\begin{array}{l}\text { Summer } \\
\text { season } \\
\text { (Apr-Jul) }\end{array}$ & $\begin{array}{c}\text { Rainy season } \\
\text { (Aug-Nov) }\end{array}$ \\
\hline 1. & Achlya americana & $15.3-17.2$ & $9.8-12.4$ & $18.4-22.9$ \\
\hline 2. & A. apiculata & $9.4-10.2$ & $5.4-8.3$ & $15.3-17.8$ \\
\hline 3. & A conspicua & $6.4-7.8$ & $3.4-6.4$ & $9.0-10.9$ \\
\hline 4. & A. prolifera & $8.4-9.9$ & $4.6-5.1$ & $10.2-12.6$ \\
\hline 5. & Allomyces anomalus & $2.0-4.3$ & $0-2.1$ & $6.2-8.4$ \\
\hline 6. & Aphanomyces laevis & $2.6-4.0$ & $0-1.3$ & $6.4-8.1$ \\
\hline 7. & Aspergillus fumigatus & $3.1-5.2$ & $1.6-2.6$ & $11.1-14.2$ \\
\hline 8. & A. niger & $5.8-8.4$ & $2.3-4.6$ & $10.4-13.8$ \\
\hline 9. & Pythium aphanidesematum & - & - & $3.2-6.4$ \\
\hline 10. & P. undulatus & $3.2-6.3$ & - & $8.1-9.6$ \\
\hline 11. & Saprolegnia hypogyna & $3.7-5.3$ & - & $7.2-10.7$ \\
\hline 12. & S. parasitica & $1.6-3.8$ & - & $4.2-5.6$ \\
\hline 13. & Hiraustitheca sp. & - & - & $3.7-4.7$ \\
\hline 14. & Chaetomium globosum & - & - & $2.4-3.5$ \\
\hline 15. & Dychuchus sp. & - & - & $1.2-3.4$ \\
\hline 16. & Alknaria tenuis & - & - & $3.2-4.1$ \\
\hline
\end{tabular}

Table.2 Fungal infection in the various fishes collected from the field of Mayanur Dam

\begin{tabular}{|r|l|r|}
\hline S. No. & \multicolumn{1}{|c|}{ Fungal Species } & Percentage \\
\hline 1. & Catla catla & 20.9 \\
\hline 2. & Labeo rohita & 10.1 \\
\hline 3. & Chirhinus murigala & 13.6 \\
\hline 4. & Clariasba trachus & 19.4 \\
\hline 5. & Mystus vittatus & 9.7 \\
\hline 6. & Anabas testudineus & 8.2 \\
\hline 7. & Oreochromis mossabicus & 18.1 \\
\hline
\end{tabular}


Table.3 Percentage of infection of the various species during the three seasons of Mayanur Dam

\begin{tabular}{|c|l|r|r|r|}
\hline S. No. & \multicolumn{1}{|c|}{$\begin{array}{c}\text { Species of Fishes } \\
\text { Pre-summer } \\
\text { season } \\
\text { (Dec-Mar) }\end{array}$} & $\begin{array}{c}\text { Summer } \\
\text { season } \\
\text { (Apr-Jul) }\end{array}$ & $\begin{array}{c}\text { Rainy season } \\
\text { (Aug-Nov) }\end{array}$ \\
\hline 1. & Achlya americana & 20.4 & 26.1 & 15.2 \\
\hline 2. & A. apiculata & 16.2 & 18.4 & 10.1 \\
\hline 3. & A conspicua & 4.3 & 14.3 & 5.6 \\
\hline 4. & A. prolifera & 14.2 & 16.1 & 7.1 \\
\hline 5. & Allomyces anomalus & 3.1 & 4.6 & 5.4 \\
\hline 6. & Aphanomyces laevis & 4.1 & 5.7 & 5.1 \\
\hline 7. & Aspergillus fumigatus & 6.4 & 2.2 & 8.7 \\
\hline 8. & A. niger & 9.8 & 12.6 & 7.3 \\
\hline 9. & Pythium aphanidesematum & - & - & 5.2 \\
\hline 10. & P. undulatus & 11.1 & - & 6.4 \\
\hline 11. & Saprolegnia hypogyna & 6.2 & - & 5.2 \\
\hline 12. & S. parasitica & 3.4 & - & 4.2 \\
\hline 13. & Hiraustitheca sp. & - & - & 4.8 \\
\hline 14. & Chaetomium globosum & - & - & 3.3 \\
\hline 15. & Dychuchus sp. & - & - & 2.2 \\
\hline 16. & Alknaria tenuis & - & - & 4.2 \\
\hline
\end{tabular}

The fungal infection in the various fishes grown in the system is presented in Table 2. As evident from the table, the fungal infection was found to vary from 8.2 to $20.9 \%$; while the maximum infection was found in Catla catla, the lowest infection occurred in Anabas testudineus.

The percentage of infection of the various fungal species during the three seasons is presented in Table 3.

As seen from the table, during the presummer season, maximum infection was shown by $A$. americana $(20.4 \%)$ and the least by Saprolegnia parasitica (3.4\%). During the summer season, again the maximum percentage of infection was shown by $A$. americana $(26.1 \%)$ while the least was shown by Aspergillus fumigatus (2.2\%). In the rainy season also, the maximum percentage of infection was recorded by $A$. americana $(15.2 \%)$ while the minimum infection was by
Tychuchus (2.2). Thus, it is clear that the maximum infection was shown by $A$. americana for all seasons. Similar observations were also recorded by various workers in different aquatic system in India (Khulbe and Sati, 1981; Sati, 1991; Chauhan and Qureshi, 1994; Qureshi et al., 2002; Jamaluddin et al., 2004; Hussain et al., 2011; Rashmi Kumari and Chandan Kumar, 2015).

\section{References}

Barnett, H. L. and Hunter, B. B. 1972. Illustrated Genera of Imperfect Fungi. $3^{\text {rd }}$ ed. Minneapolis. Burgess Publishing House, Minnesota, USA.

Bilgrami, K.S., Jamaluddin, S. and Rhizwi, M.A. 1991. Fungi of India: List and References. Today and tomorrow's Printers and Publishers, $2^{\text {nd }}$ edn. New Delhi, pp.798.

Chauhan, R. and Qureshi, T. A. (1994). Host range studies of Saprolegnia ferax and 
S. hypogyana. J. Inland Fish. Soc. India, 26: 99-106.

Cooney, D. G. and Emerson, R. 1964. Thermophilic fungi: An account of their biology, activities, and classification. W. H. Freeman \& Co., San Francisco.

Domsch, K. H., Gams, W. and Anderson, T. H. 1980. Compendium of Soil Fungi. Vol. 2. Academic Press (London) Ltd.

Hussain, S. M., Javed, M., Javid, A., Javid, J. and Hussain, N. 2011. Growth responses of Catla catla, Labeorohita and Cirrhinamrigala during chronic exposure of iron. Pak. J. Agric. Sci., 48: 225-230.

Jamaluddin, S., Goswami, M. S. G. and Ojha, B. M. 2004. Fungi of India (19882001). Scientific Publisher, Jodhpur, Rajasthan, India. pp. 326.

Khulbe, R. D. and Sati, S. C. 1981. Studies on Parasitic water molds of Kumaun Himalaya; host range of Achlya Americana Humphrey on certain temperate fish. Mykosen. 24: 177-180.

Qureshi, T. A., Chauhan, R. and Mastan, S. A. 2002. Experimental infection of Saprolegnia sp. on different species of fishes. J. Nat. Con., 14: 385-388.
Raper, K. B. and Thom, C. 1949. A Manual of the Penicillia. Williams and Wilkins Co., Baltimore. pp. 875.

Rashmi Kumari and Chandan Kumar 2015. Fungal infection in some economically important fresh water fishes in Gandak River near Muzaffarpur region of Bihar. International Journal of Life Science \& Pharma Research, 5: 1-11.

Roberts, R. J., Willoughby, L. G. and Chinabut, S. 1993. Mycotic aspects of epizootic ulcerative syndrome (EUS) of Asian fishes. Journal of Fish Diseases. 16:169-183.

Samson, R. A. and Tansey, M. R. 1977. Guide to thermophilic and thermotolerant fungi. Second International Mycological Congress, Tampa, Florida, USA.

Sati, S. C. 1991. Aquatic fungi parasitic on temperate fishes of Kumaun Himalya, India. Mycoses, 34: 9-10.

West, P. V. 2006. Saprolegniaparacitica, an oomycyte pathogen with a fishy appetite: New challenges for an old problem. Mycologist, 20: 99-104.

\section{How to cite this article:}

Bharath Kumari, K. and Sivakami, R. 2018. An Analysis of Fungal Infection in Some Economically Important Freshwater Fishes of Mayanur Dam, Karur District, Tamil Nadu, India. Int.J.Curr.Microbiol.App.Sci. 7(01): 1062-1066. doi: https://doi.org/10.20546/ijcmas.2018.701.128 